\title{
Przykład budowy heterolitologicznych pułapek złożowych w NW części zapadliska przedkarpackiego
}

\begin{abstract}
W północno-zachodniej części zapadliska przedkarpackiego występują złoża gazu i ropy naftowej, dla których pułapkę złożową stanowią zróżnicowane litologicznie i stratygraficznie utwory jury, kredy oraz miocenu. Układ poszczególnych poziomów litologicznych, następstwa warstw, zjawisk erozyjnych i procesów sedymentacyjnych spowodowały, że ich wzajemne relacje w obrębie złoża heterogenicznego są zupełnie inne niż w przypadku tradycyjnych złóż mioceńskich. W tym konkretnym przypadku przeanalizowano złoże gazu w rejonie Swarzów-Dąbrowa Tarnowska, dla którego skałami zbiornikowymi były wapienie jury, piaskowce cenomanu oraz wapienie turonu. Główny nacisk położono na niedoceniane utwory jury oraz formy krasowe, które mogą tu występować w strefie złożowej, a których dotychczas nie uwzględniano jako przestrzeni zbiornikowej w złożach tej części zapadliska. Przedstawiono też, jak opróbowanie i sposób rozwiercania złoża mogą poprawić i ułatwić eksploatację tego typu złoża.
\end{abstract}

Słowa kluczowe: pułapka złożowa, zapadlisko przedkarpackie, paleokras.

\section{Example of the construction of heterolitological reservoir traps in the NW part of the Carpathian Foredeep}

In the north-western part of the Carpathian Foredeep, hydrocarbon reservoirs have developed within lithological and stratigraphic traps of Jurrasic, Cretaceous and Miocene strata. The interrelationship between the sedimentation and erosion processes within heterogenous reservoirs is different from other classic Miocene gas fields. The article describes the results of an analysis of a gas field located in Swarzów-Dąbrowa Tarnowska area, where reservoir rocks are represented by Jurrasic limestones, Cenomanian sandstones and Turonian limestones. Particular emphasis was put on underestimated Jurrasic sediments and karst forms, which may be present in the productive zone and which have not been yet considered as reservoir areas in this part of the Carpathian Foredeep. The influence of testing and drilling on exploitation improvement within that type of the reservoir was also presented.

Key words: trap reservoir, foredeep, paleokarst.

\section{Wstęp}

Na obszarze zapadliska przedkarpackiego rozpoznano wiele złóż gazu i mniej ropy naftowej, które powstały w utworach głównie miocenu autochtonicznego, zarówno pod i przed nasunięciem karpackim, jak i na dalekim przedpolu Karpat [11]. Jest też część złóż powstałych w utworach o odmiennym wieku i wykształceniu litologicznym, różniących się również parametrami petrofizycznymi skał zbiornikowych. Do tego typu należą np. złoża położone w północnej części zapadliska przedkarpackiego, w rejonie Dąbrowy Tarnowskiej-Swarzowa (rysunek 1).

Występujące tu złoża są związane z pułapkami powstałymi na granicach stratygraficznych utworów miocenu, kredy i jury $[11,12]$. Ze względu na bardzo dobre parametry skał kredowych, głównie piaskowców cenomańskich, były one uważane za główną skałę zbiornikową tych złóż $[1,2,6]$. Zalegające poniżej skały jurajskie, ograniczone od stropu powierzchnią erozyjną, były natomiast postrzegane jako drugorzędne i mało istotne jako pułapki złożowe oraz skały zbiornikowe, gdyż skały jury są tu reprezentowane przede wszystkim przez wapienie skaliste i płytowe, z natury swojej mało porowate i przepuszczalne. Tymczasem wydaje się, że w wielu przypadkach skały te mają duże znaczenie jako skały zbiornikowe dla gazu czy też ropy naftowej. 


\section{OBJAŚNIENIA:}

\begin{tabular}{|c|c|}
\hline & piętro permsko-mezozoiczne \\
\hline & $\begin{array}{l}\text { granice jednostek tektonicznych w piętrze } \\
\text { permsko-mezozoicznym }\end{array}$ \\
\hline$\because, \ldots$ & $\begin{array}{l}\text { granice chronostratygraficzne: } \\
\text { trias-jura -.......jura-kreda }\end{array}$ \\
\hline $\begin{array}{l}\text { platforme } \\
\text { pokrywa }\end{array}$ & zachodnioeuropejska: \\
\hline & $\begin{array}{l}\text { piętro } \\
\text { karbońsko-mezozoiczne }\end{array}$ \\
\hline $\begin{array}{l}\text { platform } \\
\text { podłoże }\end{array}$ & zachodnioeuropejska: \\
\hline & eksternidy waryscyjskie \\
\hline & internidy waryscyjskie \\
\hline & pasmo fałdowe Gór Świętokrzyskich \\
\hline & $\begin{array}{l}\text { podłoże neoproterozoiczne } \\
\text { bloku małopolskiego }\end{array}$ \\
\hline
\end{tabular}

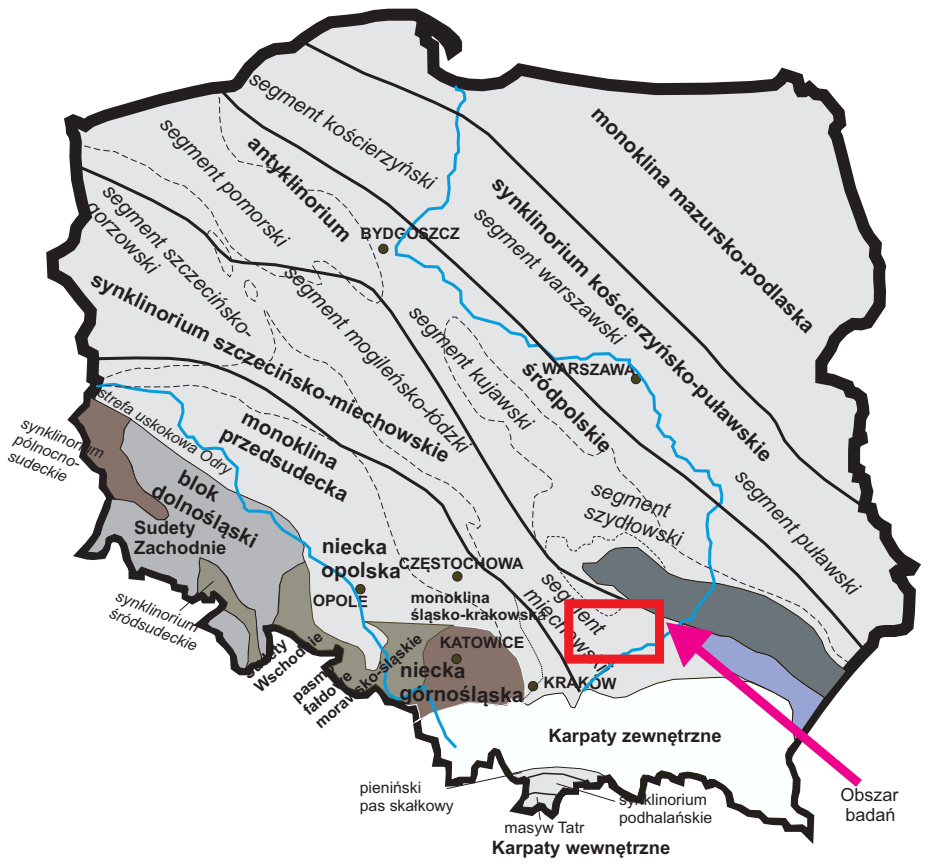

Rys. 1. Obszar badań na tle głównych jednostek tektonicznych Polski na powierzchni podkenozoicznej [według 20]

\section{Charakterystyka litologiczno-zbiornikowa skał niecki miechowskiej w rejonie Swarzów-Dąbrowa Tarnowska}

Niecka miechowska jest jednostką mezozoiczną graniczącą od NE ze zrębem świętokrzyskim, od E ze zrębem Dolnego Sanu i od W z niecką górnośląską [4, 15, 20]. Na południu jednostka przykryta jest przez jednostki płaszczowinowe Karpat. W podłożu niecki występują utwory paleozoiczne. Utwory mezozoiczne w niecce miechowskiej reprezentowane są przez $[7-9,16]$ :
- utwory triasu bez części utworów kajpru i retyku,

- utwory jury środkowej i górnej bez jej części najwyższej,

- utwory kredy górnej od utworów cenomanu po mastrycht. Utwory mezozoiku przykryte są przez utwory trzeciorzędowe, reprezentowane przez molasowe osady miocenu (rysunek 2) [15].

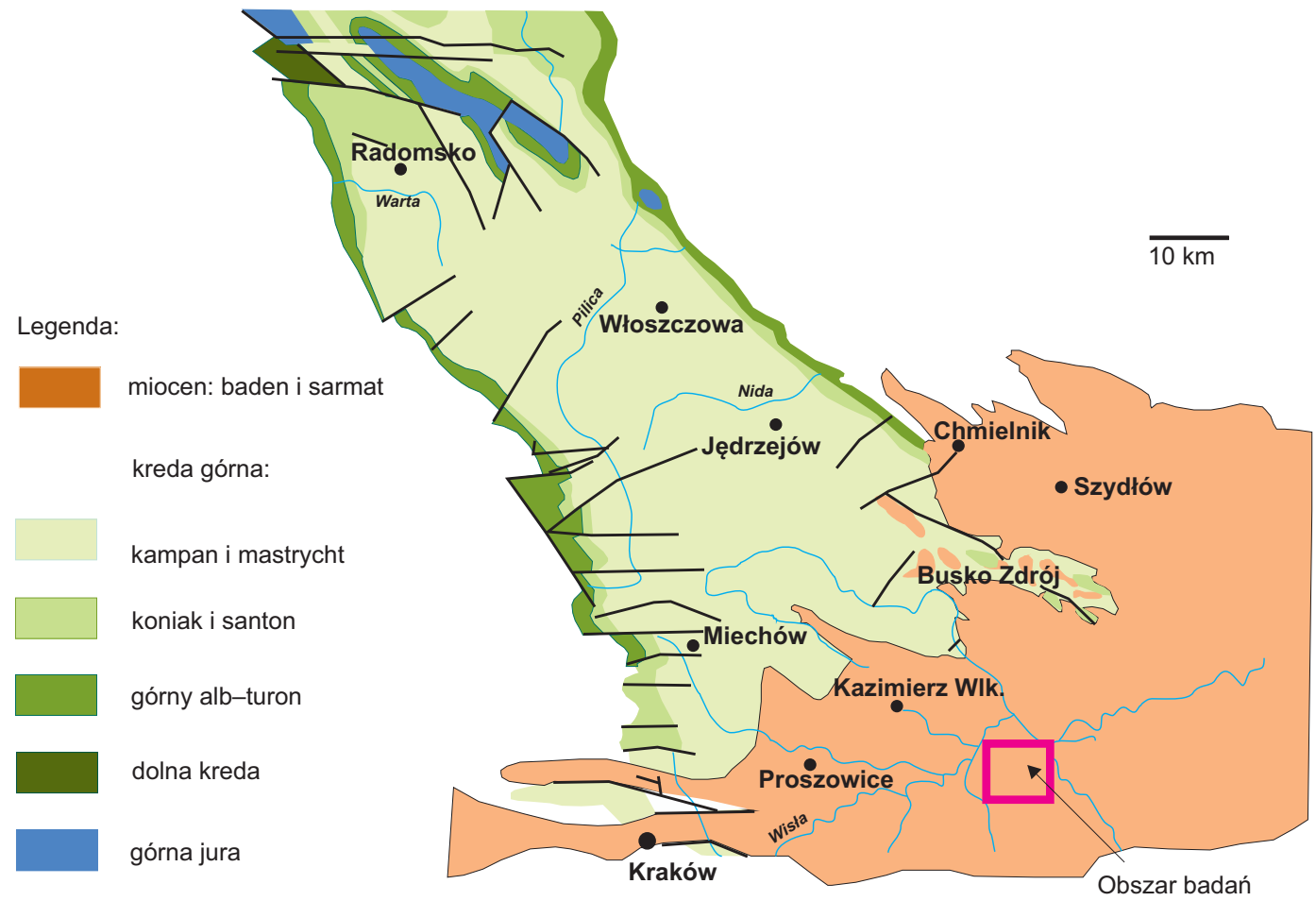

Rys. 2. Mapa rozmieszczenia utworów kredowych i mioceńskich na terenie segmentu miechowskiego i przyległej części zapadliska przedkarpackiego (prostokątem zaznaczono obszar badań) [na podstawie 15] 


\section{Litologia utworów górnej jury i górnej kredy}

\section{Górna jura}

Utwory górnej jury są tu reprezentowane przez osady węglanowe, a mianowicie: wapienie organogeniczne, oolitowe, onkolitowe, muszlowcowe oraz margle.

W badanym rejonie J. Gutowski i in. [4] wydzielają w jurze kilka nieformalnych jednostek litostratygraficznych. Są to:

- seria gąbkowo-globigerynowa - osady wapienne i marglisto-wapienne o miąższości od $68 \mathrm{~m}$ do $284 \mathrm{~m}$ na obszarze niecki miechowskiej, wiek: oksford dolny i środkowy;

- seria marglisto-wapienna - margle i wapienie mikrytowe, niekiedy o charakterze gruzłowym, barwy ciemnoszarej, wiek: oksford górny; miąższość tych osadów wynosi od kilkudziesięciu do $600 \mathrm{~m}$, w rejonie Swarzowa ponad $600 \mathrm{~m}$;

- seria koralowcowo-onkolitowa - osady wapienno-dolomityczne, niekiedy z przeławiceniami wapieni marglistych. Wapienie są wykształcone jako wapienie organogeniczne z onkolitami, muszlowcami, wapienie rafowe. Skały mają barwy od jasnoszarych, kremowych do zielonoszarych i ciemnoszarych, wiek: g. oksford-kimeryd; miąższość tych utworów na obszarze niecki miechowskiej dochodzi do $170 \mathrm{~m}$;

- seria muszlowo-oolitowa dolna - wapienie i dolomity organodetrytyczne, wapienie oolitowe i onkolitowe oraz muszlowce. Skały mają barwy od szarych, szarobeżowych do rdzawoszarych i zielonooliwkowych. W wapieniach oolitowych spotyka się warstwowanie przekątne, liczne są struktury rafowe. Miąższość na obszarze niecki miechowskiej dochodzi do $470 \mathrm{~m}$, wiek: kimeryd górny-tyton. Seria muszlowcowo-oolitowa jest najwyższym wydzieleniem górnej jury w rejonie Swarzów-Dąbrowa Tarnowska.

\section{Górna kreda}

Cenoman - utwory cenomanu reprezentowane są przez piaskowce glaukonitowe, barwy zielonej, od drobnoziarnistych do gruboziarnistych, czasami zlepieńcowatych. W dolnej części ich profilu często występują fragmenty skał jurajskich, co związane jest $\mathrm{z}$ tym, że piaskowce cenomańskie reprezentują osad transgresywny. Miąższość piaskowców w rejonie Swarzów-Dąbrowa Tarnowska wynosi od 0 do $12 \mathrm{~m}$. Piaskowce w tym rejonie ulegają wyklinowaniu erozyjnemu w kierunku NE.

Turon - utwory turonu wykształcone są jako wapienie i margle oraz wapienie margliste, popielate, szare, kremowe. Utwory te w dolnej części są zapiaszczone, a same wapienie często spękane.

\section{Powierzchnia erozyjna jury (podkredowa)}

Powierzchnia erozyjna jury jest powierzchnią strukturalną oddziałującą na litologię osadów jury oraz ich parametry petrofizyczne.
Po sedymentacji utworów górnej jury rejon niecki miechowskiej został dźwignięty i podlegał procesom erozyjnym, które trwały aż do cenomanu. Procesy erozji doprowadziły do częściowego zróżnicowania powierzchni jurajskiej i powstania wyniesień w postaci ostańców erozyjnych, tworzących garby wysokości do kilkudziesięciu metrów, o przebiegu NW-SE. Należy sądzić, że obok normalnych procesów erozyjnych, jak np. wietrzenie, erozja, abrazja itp., na omawianym obszarze odbywały się również intensywne procesy paleokrasowe związane z utworami wapiennymi górnej jury, które powszechnie występują tu na powierzchni erozyjnej. Biorąc pod uwagę ciepły i wilgotny klimat, jaki panował w tym czasie, procesy krasowe musiały być bardzo intensywne [3, 5, 10, 16-18].

Procesy wietrzeniowe doprowadziły do tego, że utwory zalegające poniżej powierzchni erozyjnej uległy silnemu spękaniu, czasami dezintegracji i wymieszaniu z materiałem cenomańskim oraz pochodzącym $\mathrm{z}$ wietrzenia materiałem rezydualnym. Strefa silnego zwietrzenia ma miąższość od 0 do kilku metrów, natomiast oddziaływanie procesów wietrzeniowych sięga zapewne znacznie głębiej (rysunek 3 ).

Parametry petrofizyczne strefy wietrzenia są zróżnicowane. Tam, gdzie proces spękania, skawernowania, zniszczenia skał wapiennych jest duży, a objętości międzyskalne zostały wypełnione przez osady piaszczyste cenomanu, należy spodziewać się lepszych parametrów.

Natomiast tam, gdzie skała jest mniej zwietrzała i bardziej lita, parametry petrofizyczne są niższe. W partiach mało zwietrzałych, gdzie występują wapienie skaliste i płytowe, możemy spodziewać się niskich wielkości parametrów petrofizycznych [12]: porowatość od $0 \%$ do około $2,5 \%$. W partiach wapieni organodetrytycznych, rafowych porowatość może być wyższa. Przepuszczalność wapieni też jest niska i wynosi poniżej $0,1 \mathrm{mD}$, sporadycznie więcej. W partiach zwietrzałych porowatość tej strefy wynosi około $7 \div 8 \%$ [12], zaś średnia przepuszczalność - $175 \mathrm{mD}$.

Poniżej strefy silnie zwietrzałej wapieni jurajskich występuje strefa, gdzie stopień zniszczenia skał jest znacznie mniejszy. Zostały tu stwierdzone spękania, szczeliny, kawerny, a w kilku przypadkach także pokrywy żelaziste. Struktury te są puste, niewypełnione, czasami wypełnione substancją rezydualną (iły, okruchy skalne, piasek) lub osadem piaszczystym cenomanu, spotykano też wypełnienia kalcytem [14]. Spękania i kawerny występujące w tej części nasuwają przypuszczenia, że ich obecność wiąże się też z możliwością występowania innych wielkoskalowych zjawisk krasowych tworzących pogrążony paleokras. Biorąc pod uwagę fakt, że obszar poddany był erozji, przez całą dolną kredę musiały wytworzyć się na nim podpowierzchniowe zjawiska krasowe w postaci lejów krasowych, studni, kominów, korytarzy, komór, jaskiń itp. 


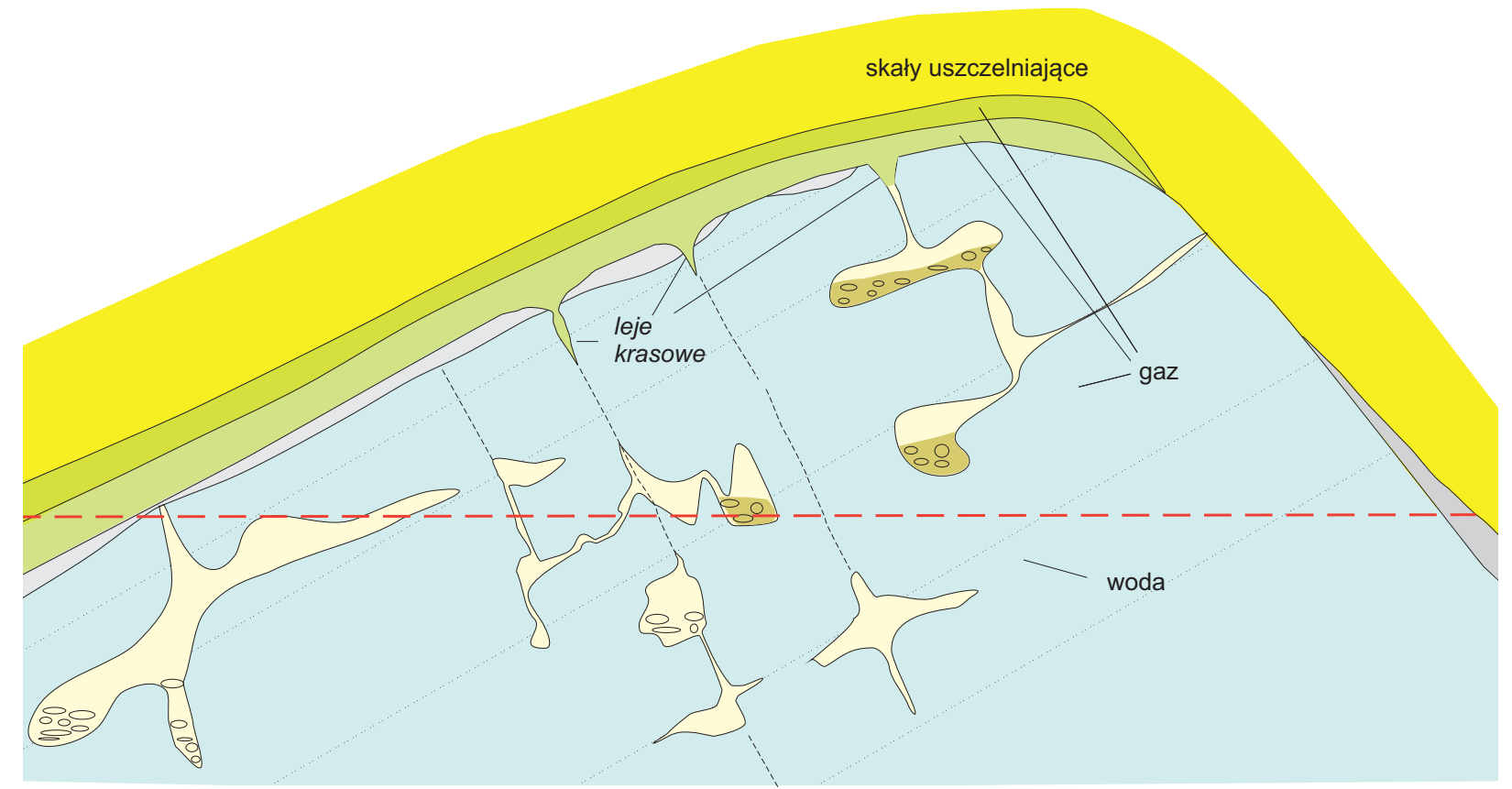

Objaśnienia:

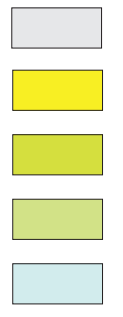

zwietrzelina jurajska, dolnokredowa

senon-margle

wapienie turonu

cenoman-piaskowce

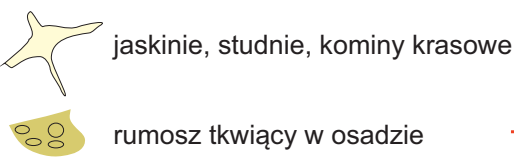

spękania i szczeliny

- kontur gaz-woda

jura górna-wapienie i margle

Rys. 3. Kontakt erozyjny wapieni jurajskich z piaskowcami cenomanu na obszarze złoża gazu [rysunek własny]

Najczęściej rozwój zjawisk krasowych wiąże się z lokalnym układem spękań i szczelin tektonicznych. W rejonie Swarzów-Dąbrowa Tarnowska w wierceniach stwierdzono obecność zespołów spękań tektonicznych w wapieniach, lecz nie były one ani mierzone, ani orientowane. Wiadomo natomiast, że w badanym rejonie warstwy zapadają monoklinalnie na SW, a oś niecki miechowskiej ma kierunek NW-SE. Stąd można wysnuć wniosek, że w czasie tworzenia się niecki układ naprężeń głównych przebiegał na kierunku NE-SW. W tej sytuacji tektonicznej mógł wytworzyć się podwójny system spękań: pierwszy to system spękań podłużnych na kierunku NW-SE, a drugi to system spękań poprzecznych na kierunku NE-SW. Do kierunku NW-SE nawiązują struktury jurajskie występujące w stropie powierzchni erozyjnej, podgórnokredowej. Przyjmując taki system spękań, należy sądzić, że kras rozwijał się właśnie na tych kierunkach, czyli NW-SE i prostopadłym do niego kierunku NE-SW. Najszybciej zjawiska krasowe mogły rozwijać się tam, gdzie szczeliny krzyżowały się i były otwarte, a woda mogła w nie wnikać i rozpuszczać skały wapienne, tworząc najpierw leje krasowe, potem studnie i kominy. W późniejszym czasie dochodziło do łączenia tych form krasowych po- przez system korytarzy i jaskiń. Najszybciej zjawiska krasowe mogły się tworzyć na zboczach i ich podnóżach, czyli w miejscach, gdzie wody było najwięcej. Podziemne połączenia form krasowych tworzą często skomplikowany i rozległy system. Powierzchnia erozyjna jury została najpierw przykryta osadami górnej kredy, później ponownie poddana erozji w paleogenie i ostatecznie przykryta osadami miocenu i czwartorzędu. Formy krasowe przypowierzchniowe i powierzchniowe zostały wypełnione i przykryte przez młodsze osady. Jeśli chodzi o głębsze formy krasowe, to częściowo mogły zostać wypełnione przez młodsze osady, ale biorąc pod uwagę skomplikowany system, jaki tworzą, większość form pozostała wolna, wypełniona wodą słodką lub morską, lub w sprzyjających warunkach węglowodorami: gazem lub ropą, np. Swarzów, Dąbrowa Tarnowska.

\section{Charakterystyka poziomów skal zbiornikowych na przykladzie złoźa gazu Swarzów}

Złoże gazu ziemnego Swarzów występuje w południowej części niecki miechowskiej. Jest to złoże występujące w zróżnicowanej pod względem litologicznym strukturze (rysunek 4). Skałami zbiornikowymi dla gazu były tutaj utwory 
górnej jury i górnej kredy ekranowane od góry utworami senonu oraz miocenu [13].

Szczegółowy profil skał zbiornikowych złoża jest następujący (od góry profilu):

- wapienie turonu,

- piaskowce cenomanu zalegające transgresywnie na skałach jurajskich,

- wapienie górnej jury ścięte w stropie przez powierzchnię erozyjną.

Za główną skałę zbiornikową uważane były piaskowce cenomanu, następnie wapienie jury oraz wapienie turonu. Złoże ograniczone jest konturem wody, pierwotnie uważanym za okalający. Wszystko jednak wskazuje na to, że jest to kontur podścielający.

Charakterystyka poszczególnych poziomów zbiornikowych złoża jest następująca [12]:

- Poziom zbiornikowy wapieni turonu - jest to poziom zbudowany ze spękanych, częściowo zapiaszczonych wapie- ni turonu o zmiennej i niedużej miąższości, wynoszącej od 0 do około $5 \mathrm{~m}$. Poziom wyklinowuje się ku NE, natomiast rozwija się w kierunku SW. Brak go w części E złoża. Leży w ciągłości sedymentacyjnej piaskowców cenomańskich, o czym świadczą pojedyncze wkładki piaskowców cenomańskich w dolnej części profilu wapieni turonu. Porowatość skał wynosi od 1\% do 16\%.

- Poziom zbiornikowy piaskowców cenomańskich - jest to bardzo dobry poziom zbiornikowy, który budują piaskowce, od drobnoziarnistych do gruboziarnistych, w dolnej części zlepieńcowaty, zawierający fragmenty skał starszych. Piaskowiec jest często rozsypliwy, słabo zwięzły, czasem występujący w postaci piasku. Piaskowiec cenomański jest osadem transgresywnym, który został zdeponowany na jurajskiej powierzchni erozyjnej. Powierzchnia ta była zapewne nierówna, pokryta rumoszem skalnym, ostańcami erozyjnymi, lejami i bruzdami krasowymi, wylotami

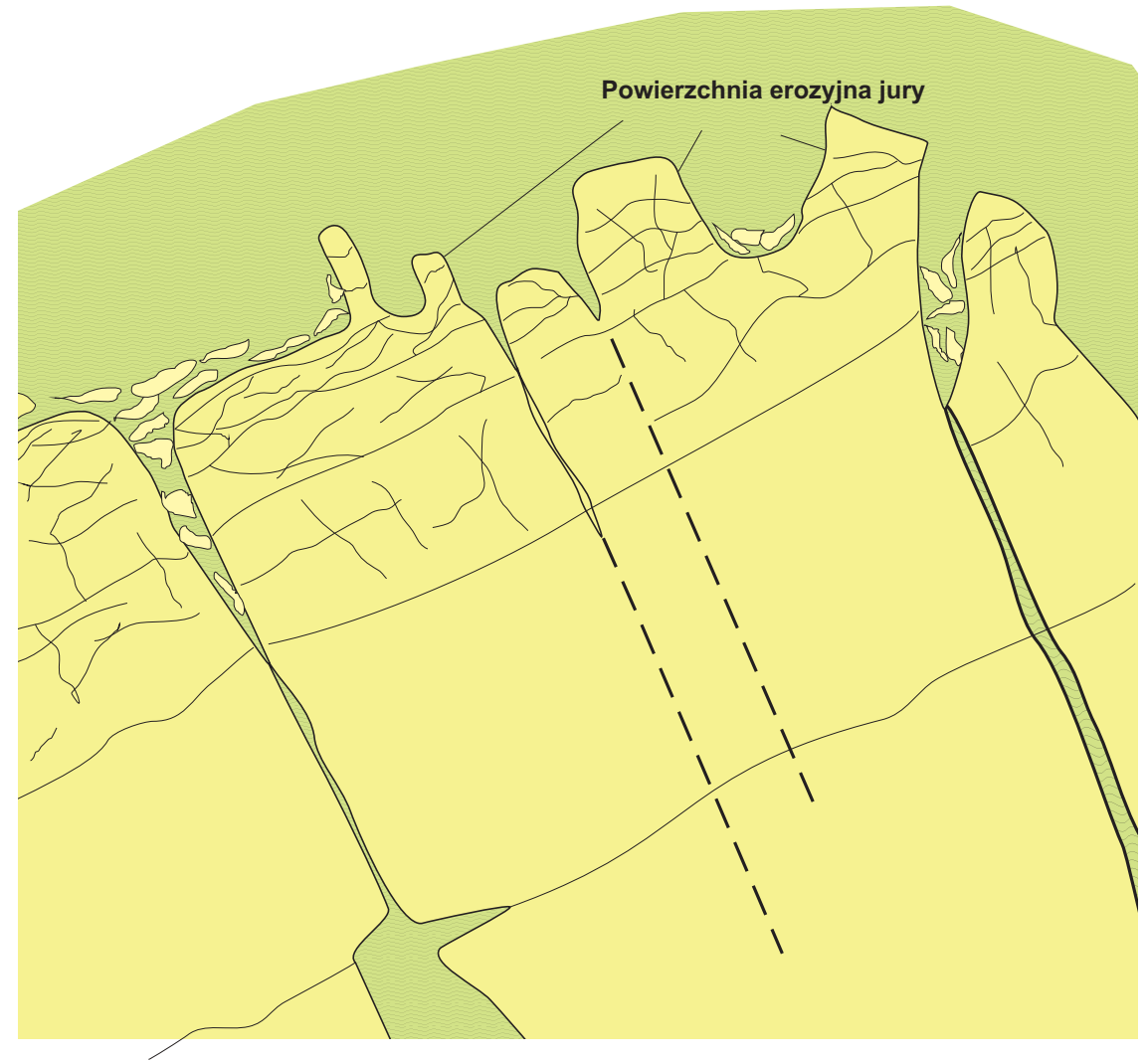

Objaśnienia:

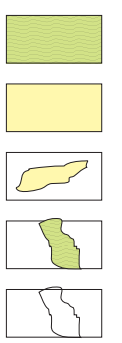

cenoman-piaskowce

jura-wapienie

rumosz wapieni jurajskich

szczeliny, kominy krasowe wyp. piaskowcami cenom.

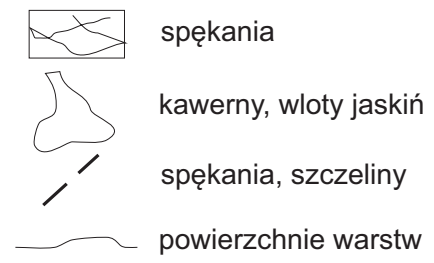

szczeliny, kominy krasowe bez wypełnienia

Rys. 4. Schemat złoża heterolitologicznego w wapieniach jury, piaskowcach cenomanu i wapieniach turonu w rejonie Swarzów-Dąbrowa Tarnowska [rysunek własny] 
spękań, szczelin, studni i kominów krasowych oraz innych form krasowych. W tej sytuacji deponowane piaskowce w pierwszym rzędzie wypełniały częściowo lub całkowicie te struktury i wyrównywały dno zbiornika. Wynika stąd, że spąg piaskowca cenomańskiego nie jest płaską powierzchnią, ale silnie postrzępioną. Parametry petrofizyczne piaskowca są bardzo dobre: porowatości wynoszą $3 \div 35 \%$, a przepuszczalności od $0 \mathrm{mD}$ do ponad $6 \mathrm{D}$.

- Poziom zbiornikowy wapieni jurajskich - jest zbudowany z wapieni jurajskich, ściętych przez powierzchnię erozyjną, dolnokredową i częściowo paleogeńską. Poziom jurajski ze względów litologiczno-złożowych można podzielić na dwa elementy: poziom górny - wapienny, zwietrzelinowo-paleokrasowy i poziom dolny - wapienny, paleokrasowy. Poziom dolny podścielony jest wodą złożową.

- Poziom górny - wapienny, zwietrzelinowo-paleokrasowy obejmuje strefę zwietrzeliny wapieni jurajskich, jaka została wytworzona podczas procesów erozyjnych w czasie dolnej kredy, a w części wschodniej złoża także podczas paleogenu. Miąższość zwietrzeliny można ocenić na od 0 do kilku metrów, co świadczy, że w pewnych rejonach może tworzyć płaty zwietrzeliny, w innych bardziej ciągły poziom, a może też w ogóle nie występować. Poziom zwietrzelinowy wykształcony jest w postaci wapiennych okruchów, głazów, odłamków skalnych, często spękanych, zwietrzałych, skawernowanych, zalegających na sobie. Wolne przestrzenie między okruchami mogą być wypełnione materiałem rezydualnym lub piaskowcem cenomańskim. Materiał ten zalega na silnie spękanych, połamanych, zwietrzałych, podkredowych wychodniach ławic wapieni, czasami margli. Strefa zwietrzenia zanika ku dołowi. Parametry zbiornikowe tej strefy są zróżnicowane, porowatość średnia wynosi $7 \div 8 \%$, a przepuszczalność może wahać się w dużym zakresie, w zależności od obecności spękań i materiału wypełniającego przestrzeń międzyokruchową. Na obszarze złoża łączność tej strefy zwietrzelinowej z piaskowcami cenomanu należy uznać za bardzo dobrą w strefie występowania piaskowców, natomiast w części wschodniej, gdzie brak jest piaskowców, kontakt może być utrudniony. Słabszy kontakt z piaskowcem może być też spowodowany gorszymi parametrami materiału okruchowego.

- Poziom dolny - wapienny, paleokrasowy - poziom ten dotychczas nie był uwzględniany jako skała zbiornikowa, był całkowicie pomijany. Budują go wapienie skaliste i płytowe, organodetrytyczne, których parametry są zasadniczo bardzo słabe. W przypadku wapieni skalistych i płytowych ich porowatość wyno- si $0 \div 2,5 \%$, a w przypadku wapieni organodetrytycznych, rafowych jest wyższa. Również przepuszczalność matrycy wapieni skalistych i płytowych jest bardzo niska, wynosi poniżej $0,1 \mathrm{mD}$, natomiast dla wapieni organodetrytycznych jest ona wyższa. Strefa ta jednak charakteryzuje się też innymi cechami, a mianowicie obecnością spękań ciosowych oraz form krasowych. W przypadku spękań występuje tu system spękań równoległych oraz system spękań prostopadłych (spękania takie opisywane są w rdzeniach, ale nie zostały zidentyfikowane odnośnie do przynależności do poszczególnych zespołów spękań). Spękania są wolne albo częściowo lub całkowicie zabliźnione kalcytem, materiałem rezydualnym lub młodszym materiałem osadowym. Znacznie istotniejsze, jak się wydaje, są formy krasowe, jakie mogą tu występować. Podczas wierceń opisywane były skawernowane wapienie oraz nacieki żelaziste obecne w kawernach lub szczelinach, zostały też stwierdzone osady rezydualne będące pozostałością po procesach krasowych lub wypełnienia materiałem obcym, odmiennym litologicznie od skał otaczających. Fakty te dowodzą istnienia w opisywanym rejonie form krasowych, którymi mogą być obok szczelin: studnie i kominy krasowe, korytarze, komory, jaskinie, syfony itp. Formy te mogą być od siebie izolowane, mogą też tworzyć jeden lub więcej wspólnych systemów. Łączność form krasowych lub jej brak decyduje, jaki jest ich system hydrodynamiczny. Poziom paleokrasowy zalega albo pod poziomem zwietrzelinowym albo w przypadku jego braku - bezpośrednio pod piaskowcem cenomańskim, który to częściowo lub całkowicie może wypełnić te formy. Łączność poziomu paleokrasowego z nadległą częścią złoża jest dosyć skomplikowana. Poziom ten może łączyć się z wyższymi poziomami albo punktowo, np. u wylotu studni i kominów krasowych, albo linijnie, jak np. w przypadku spękań i szczelin. Łączność taka może istnieć jedynie wtedy, jeżeli te formy są drożne lub wypełnione materiałem przepuszczalnym. Poziom paleokrasowy może bezpośrednio występować pod piaskowcem cenomańskim, ale aby był hydrodynamicznie połączony z piaskowcem, formy krasowe muszą bezpośrednio łączyć się z tym poziomem. Jeśli ponad poziomem paleokrasowym występuje poziom zwietrzelinowy, formy krasowe łączą się z pozostałymi poziomami poprzez ten poziom. Wtedy łączność hydrodynamiczna jest warunkowana parametrami poziomu zwietrzelinowego. Punktowa i liniowa łączność powoduje, że przepływy mediów złożowych z poziomu paleokrasowego mogą być bardzo skomplikowane. 


\section{Wpływ opróbowania odwiertów w złożach heterolitologicznych na eksploatację tych złóż}

W przypadku złóż zbudowanych z kilku poziomów o odmiennym charakterze litologicznym, jak ma to miejsce np. w złożu Swarzów, sposób rozwiercania i opróbowania poziomu może być istotnym problemem we właściwej eksploatacji złoża. W przypadku wapieni turońskich i piaskowców cenomanu oraz części poziomu zwietrzelinowego wapieni jurajskich opróbowanie w otworze całości lub części któregokolwiek z tych poziomów zapewnia dobrą łączność hydrodynamiczną tych warstw. Natomiast opróbowanie poziomu paleokrasowego jest skuteczne jedynie wtedy, kiedy odwiert trafi w strefę oddziaływania połączenia punktowego lub liniowego (może być zespół spękań). Natomiast w przypadku opróbowania skały płonnej nie uzyskamy połączenia poziomu paleokrasowego z otworem w tym miejscu. Wtedy gaz płynie okrężną drogą z punktowych połączeń poziomu paleokrasowego poprzez poziom zwietrzelinowy i piaskowce cenomanu do najbliższego otworu. Droga gazu jest długa i kręta.

W przypadku gdy zostaną opróbowane jedynie poziomy turonu i cenomanu, łączność hydrodynamiczna z niżej ległym poziomem zwietrzelinowym zostanie uzyskana tam, gdzie parametry tego ostatniego są dobre, natomiast przepływ z poziomu krasowego będzie punktowy lub liniowy. Przy tym transport medium złożowego z poziomu paleokrasowego i jego droga do otworu będą zależały od położenia otworu względem punktowych i liniowych połączeń tego poziomu. Gdy droga jest długa, rosną opory przepływu i wzrasta czas dopływu gazu do otworu, a jednocześnie w przypadku blisko leżącego konturu wody może dochodzić do podciągania wody złożowej do odwiertu. Częściowym rozwiązaniem tego problemu może być sposób rozwiercania złoża. Przy punktowym lub liniowym połączeniu poziomu krasowego trudno jest trafić otworem w takie miejsce. Dobrym wyjściem może być wykonanie otworu kierunkowego lub horyzontalnego do serii zbiornikowej. Odwiert powinien być odwiercony w kierunku prostopadłym lub ukośnie do systemu spękań równoległych występujących w poziomie paleokrasowym. Taka trajektoria otworu, przy rozpoznanej gęstości spękań i ich azymutów, powinna umożliwić przecięcie otworu ze szczeliną, z zespołem szczelin lub jakąś formą krasową, a to pozwoliłoby uzyskać zdecydowanie lepszą łączność z poziomem krasowym oraz umożliwiłoby obniżenie depresji w strefie przykonturowej piaskowców cenomanu i wapieni turonu.

\section{Wnioski}

1. W złożach heterolitologicznych zapadliska przedkarpackiego z udziałem skał jurajskich oprócz poziomu zwietrzelinowego jury należy rozpatrzyć możliwości zbiornikowe strefy wapieni z formami krasowymi znajdującej się poniżej ich strefy zwietrzałej.

2. W celu dobrego udostępnienia poziomu krasowego konieczne jest rozpoznanie przestrzennego położenia syste- mów spękań i szczelin na złożu oraz dokonanie oceny możliwości występowania różnego rodzaju form krasowych.

3. Najlepszym sposobem opróbowania i udostępnienia złóż z udziałem skrasowiałych wapieni jurajskich jest rozwiercenie ich za pomocą otworów kierunkowych lub horyzontalnych z trajektorią wynikającą z przebiegu spękań i szczelin.

Prosimy cytować jako: Nafta-Gaz 2018, nr 7, s. 495-502, DOI: 10.18668/NG.2018.07.02

Artykuł nadesłano do Redakcji 23.11.2017 r. Zatwierdzono do druku 25.05.2018 r.

Artykuł powstał na podstawie pracy statutowej pt.: Aktualizacja budowy modelu geologicznego PMG Swarzów - praca INiG - PIB na zlecenie MNiSW; nr zlecenia: 215/0052/17/01, nr archiwalny: DK-4100-39/2017.

\section{Literatura}

[1] Depowski S.: Obszary gazonośne i roponośne Polski. Przegląd Geologiczny 1981, vol. 29, nr 5, s. 209-217.

[2] Dudek J.: Warunki geologiczno-strukturalne pulapek i parametry złożowe górnej jury w zapadlisku przedkarpackim. Prace Instytutu Górnictwa Naftowego i Gazownictwa 1980, nr 37, s. 5-117.

[3] Gała I.: Wstepne rozpoznanie i charakterystyka siarczkowych wód termalnych w otworze Busko C-1. Technika Poszukiwań Geologicznych. Geotermia, Zrównoważony Rozwój 2011, nr 1-2, s. 339-348.

[4] Gutowski J., Urbaniec A., Złonkiewicz Z., Bobrek L., Świetlik B., Gliniak P.: Stratygrafia górnej jury i dolnej kredy środ- kowej części przedpola polskich Karpat. Biuletyn Państwowego Instytutu Geologicznego 2007, nr 426, s. 1-26.

[5] Jasnos J., Papiernik B., Hajto M.: Warunki geotermiczne formacji mezozoicznych niecki miechowskiej i jej podłoża kontynuujacych się pod zapadliskiem przedkarpackim i Karpatami zewnętrznymi. Technika Poszukiwań Geologicznych, Geotermia, Zrównoważony Rozwój 2016, nr 2, s. 201.

[6] Jawor E., Baran U.: Uskoki oraz ich rola w formowaniu putapek $i$ złóż ropy i gazu w platformowym podłożu przedgórza $i$ Karpat. Nafta-Gaz 2008, nr 2, s. 71-83.

[7] Jurkowska A.: Stratygrafia inoceramowa i architektura depozycji wyższej kredy górnej niecki miechowskiej. Uniwersytet 
Jagielloński, Wydział Biologii i Nauk o Ziemi, Instytut Nauk Geologicznych, rozprawa doktorska, praca dyplomowa, Kraków 2014.

[8] Kędzierski M., Kołodziej B., Hoffmann M., Machaniec E., Stworzewicz E., Szulc J.: Budowa geologiczna i paleontologia regionu krakowskiego: dolny perm, środkowa i górna jura, górna kreda. XXII Konferencja Naukowa Sekcji Paleontologicznej Polskiego Towarzystwa Geologicznego, Tyniec, 27-30.09.2013, materiały konferencyjne, s. 89-100.

[9] Lewandowski J.: Kenozoik regionu ślasko-krakowskiego. Wydawnictwo Uniwersytetu Śląskiego, Katowice 2015.

[10] Michno A.: Rozwój dolin w ujściowych odcinkach rzek na wy$\dot{z} y n a c h$ lessowych w Polsce. Uniwersytet Jagielloński, Instytut Geografii i Gospodarki Przestrzennej, Kraków 2013.

[11] Miziołek M., Filar B., Cierzniak M.: Pułapki złożowe zapadliska przedkarpackiego w czołowej strefie nasunięcia Karpat. Nafta-Gaz 2017, nr 8, s. 551-557, DOI: 10.18668/NG.2017.08.02

[12] Oszczypko N., Tomaś A.: Charakterystyka własności zbiornikowych osadów jurajskich na przedgórzu Karpat środkowych. Kwartalnik Geologiczny 1978, vol. 22, nr 3, s. 585-600.

[13] Piesik-Buś W., Miziołek M.: Bilans stanu zasobów gazu ziemnego na przykładzie złóż zapadliska przedkarpackiego. Nafta-Gaz 2016, nr 11, s. 945-952, DOI: 10.18668/NG.2016.11.08.

[14] Rutkowski J.: Budowa geologiczna regionu Krakowa. Przegląd Geologiczny 1989, vol. 37, nr 6, s. 302-307.

[15] Stachacz M., Jurkowska A., Machaniec E.: Górna kreda niecki miechowskiej i miocen pótnocnej części zapadliska przedkarpackiego. XXII Konferencja Naukowa Sekcji Paleonto- logicznej Polskiego Towarzystwa Geologicznego, Tyniec, 27-30.09.2013 r., materiały konferencyjne, s. 75-87.

[16] Urban J., Chwalik-Borowiec A., Kasza A.: Warunki rozwoju $i$ wiek krasu w gipsach Niecki Soleckiej. Biuletyn Państwowego Instytutu Geologicznego 2015, nr 462, s. 125-152.

[17] Wiktorowicz B.: Możliwości wykorzystania wód termalnych centralnej części Niecki Nidy. Biuletyn Państwowego Instytutu Geologicznego 2015, nr 462, s. 179-186.

[18] Wiktorowicz B., Nowak J.: Wody geotermalne rejonu Kazimierzy Wielkiej i możliwości ich zagospodarowania. Technika Poszukiwań Geologicznych. Geotermia, Zrównoważony Rozwój 2016, nr 2, s. 45-54.

[19] Złonkiewicz Z.: Ewolucja basenu niecki miechowskiej w jurze jako rezultat regionalnych przemian tektonicznych. Przegląd Geologiczny 2006, vol. 54, nr 6, s. 534-540.

[20] Żelaźniewicz A., Aleksandrowski P., Buła Z., Karnkowski P., Konon A., Oszczypko N., Ślączka A., Żaba J., Żytko K.: Regionalizacja tektoniczna Polski. Wydawnictwo PAN, 2011.

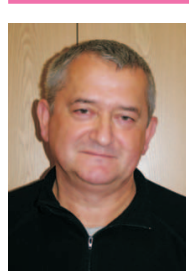

Mgr Mariusz MIZIOŁEK

Starszy specjalista badawczo-techniczny w Zakładzie Podziemnego Magazynowania Gazu.

Instytut Nafty i Gazu - Państwowy Instytut Badawczy ul. Lubicz $25 \mathrm{~A}$

31-503 Kraków

E-mail:mariusz.miziolek@inig.pl

\section{OFERTA}

\section{ZAKŁAD PODZIEMNEGO MAGAZYNOWANIA GAZU}

Zakres działania:

- $\quad$ analiza struktur geologicznych złóż gazu ziemnego, ropy naftowej oraz obiektów zawodnionych, pod kątem możliwości ich przekształcenia w PMG;

- $\quad$ szczegółowa analiza warunków geologiczno-złożowych, ocena dotychczasowej eksploatacji złoża, warunków hydrodynamicznych, zdolności wydobywczych odwiertów;

- ocena stanu technicznego istniejącej infrastruktury w aspekcie jej wykorzystania w pracy PMG;

- wykonywanie cyfrowych modeli geologicznych PMG, złóż gazu ziemnego i ropy naftowej;

- $\quad$ wykonywanie projektów budowy PMG;

- $\quad$ analiza dotychczasowej pracy istniejących PMG w celu optymalizacji parametrów dalszej eksploatacji magazynów na bazie symulacji komputerowej;

- opracowywanie projektów prac geologicznych, dotyczących poszukiwania i rozpoznawania złóż gazu ziemnego i ropy naftowej;

- $\quad$ opracowywanie dokumentacji geologicznych złóż ropy naftowej i gazu ziemnego;

- $\quad$ opracowywanie programu optymalnej eksploatacji złoża, wydajności poszczególnych odwiertów, tempa sczerpywania itp.

Kierownik: mgr inż. Bogdan Filar

Adres: ul. Armii Krajowej 3, 38-400 Krosno

Telefon: 134368941 w. 5202

Faks: 134367971

E-mail: bogdan.filar@inig.pl

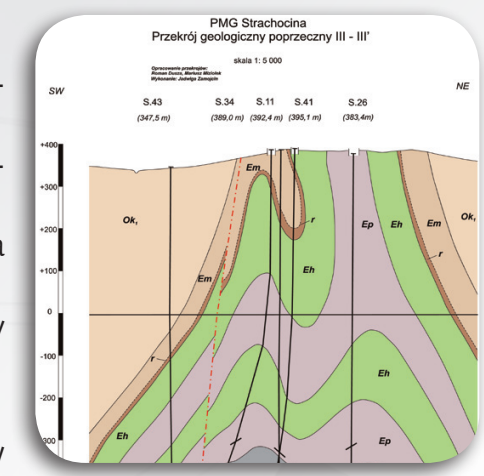

$=$

$\begin{array}{llll}5.34 & 5.11 & 5.41 & 3.20\end{array}$
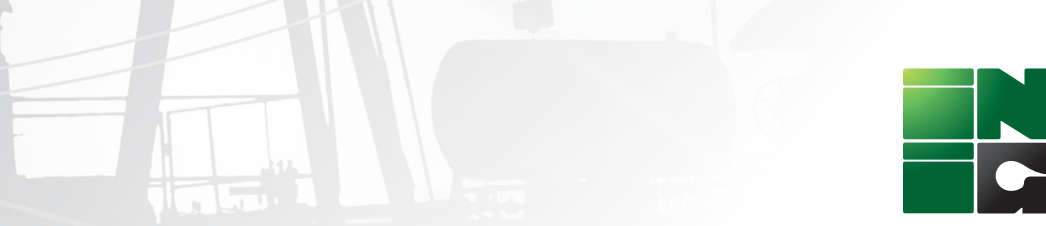